\title{
The Most Frequent Errors in Academic Writing: A Case of EFL Undergraduate Arab Students in Israel
}

\author{
Wisam Chaleila ${ }^{1}$ \& Iman Garra-Alloush ${ }^{1}$ \\ ${ }^{1}$ Department of English, Al-Qasemi College of Education, Baqa Elgharbia, Israel \\ Correspondence: Wisam Chaleila, Department of English, Al-Qasemi College of Education, Baqa Elgharbia, \\ Israel.
}

Received: May 13, 2019 Accepted: June 17, 2019 Online Published: June 19, 2019

doi: 10.5539/elt.v12n7p120 URL: https://doi.org/10.5539/elt.v12n7p120

\begin{abstract}
The current study examined the most common types of academic writing errors and the causes of such errors made by 44 tertiary EFL Arab-Israeli students. A methodological triangulation was employed in this research. Results and analyses of errors in the written samples revealed that students made a substantial number of errors in both rating scales. In the generic writing performance scale (the qualitative method), 75\% of students' written samples rated poor, and the error frequency rating scale (the quantitative method) showed that the students made 2965 errors, which is a notably large number in proportion to the essay length. The researchers have also inferred that the principal reason for such errors is the triglossic nature of Arabic in Israel. The novelty of this research is that such triglossic nature of Arab-Israelis' language has not yet been investigated in the field. To this end, the results drawn will be utilised in future research as a platform for exploring effective teaching approaches that may enhance EFL students' writing performance.
\end{abstract}

Keywords: academic writing, errors, tertiary level, triglossia, vernacular

\section{Introduction}

\subsection{Challenges of Academic Writing}

Writing is a core academic requirement not only of English Departments worldwide, but of other disciplines as well. As academic prestige encompasses increasing the publication record of scholars, academic writing has increasingly become a tenacious demand. Hence, many tertiary education institutions have expanded their offerings of academic writing courses recently (Smith, 2004; Al-Zubaidi, 2012). Nonetheless, writing is not a stress-free task as it involves codified rhetorical forms and critical thinking skills. In addition, the assessment of writing incorporates many challenges which make the task of writing even more arduous for EFL students who usually lack the competencies needed to fulfill such an undertaking.

The value of academic writing stems from the superior and eminent status it holds in contrast to other types of writing, i.e. non-academic writing. Basically, non-academic writing targets the masses rather than professionals. The written product may as well contain incorrect and even wrong details. It sometimes even includes outdated, prejudiced, and obsolete information. The language used in non-academic writing is ordinary, repetitive, off-the-cuff, colloquial, and most importantly, no reference list is required. Such writing is opinion-induced rather than authentic and factual. In this sense, its authority of publication is mainly restricted to social media networks, magazines and newspapers.

However, in the case of academic writing the chronicle is entirely different as it adheres to evident, unwavering, solid, and universal conventions. Academic writing further entails formality of register and language, impassiveness, objectivity, evidence, explicitness of layout and lucidity of sentence structure, let alone concision and precision (University of Sheffield 2019). Similarly, "Introduction to Academic Language" (Note 1) avows that academic writing uses formal, clear, precise, cohesive, concise, evidence-driven, stepwise, complex, and responsible rather than colloquial, emotional, chatty, descriptive, informal, idiomatic, and clichéd language. Apart from embracing a detached, unbiased, and objective approach, academic writing retains an intellectual and ofttimes a philosophical position. Its essence accounts for reason and deduction and it appeals to systematic guidelines for referencing and citation. Hence, evidence and logic are key components of academic writing. 


\subsection{Significance of the Study: A Case of Arab-Israeli EFL Students}

Unlike the general Arab World phenomenon of Arabic diglossia which, inter alia, generates hardships in academic writing performance, EFL Arab students in Israel (sometimes called Arab-Israelis or 1948 Palestinians) have to surmount another obstacle: triglossia. Ferguson (1959) defines diglossia as a language phenomenon that incorporates two languages: the first represents the main local common dialects while the second exemplifies the Modern Standard Arabic used in formal domains and which is exceedingly complex, classified, systematic, and overlapping. Triglossia, on the other hand involves code-switching and code-mixing and is outlined as "the coexistence of three languages within a speech community" (Garner, 2009, p. 1033). Indeed, in terms of frequency, Arabs in Israel use the vernacular Arabic (daily situations), Hebrew (daily situations, school and academic spheres), and Modern Standard Arabic (school). Hence, their English leaning is affected by three-faceted interferences. Furthermore (Note 2), Arabs in Israel recurrently fuse the vernacular Arabic with Hebrew. Therefore, it is reasonable to say that they have also to tackle the triglossic deficit which makes the academic writing task even more challenging. Surprisingly, only recently were such cases of intertwined languages considered as a valid practice of contact language (Thomason \& Kaufman, 1988).

In this context, interference evokes a double effect for EFL Arab-Israelis since Arabic and Hebrew are substantially different although they are both Semitic tongues. In other words, the interference is subject to two language barriers. One prominent difference between Arabic and English is that Arabic is a Semitic language with non-Roman alphabets. It is rather an abjad and therefore its orthographic system is different from the English one. While English roots are traced back to Indo-European origins, Arabic has grown from Proto-Semitic descent. Contrary to English, in Arabic the stress is on the consonantal root for the lexical meaning. Cook (1997, p. 474) emphasises the orthographic difficulty as one crucial aspect generating poor writing: "Users of an orthographically deep language [such as Arabic] might be expected to have more problems with the phonological route in an L2, users of an orthographically shallow language with the visual route."

It is also worthwhile noting that Arabic-Hebrew bilingualism is mandatory only for the Arab minority in Israel whereas for the Jewish majority it is not. In addition, the status of Modern Standard Arabic is completely absent in the Israeli academic sphere where Hebrew is the official first language and English is second. As a result, the Arab student feels forsaken, outcast, and discriminated against in such a sphere that functions as the main educational environment for Arabs and Jews alike (Amara et al., 2016, p. 7) (Note 3).

\section{Literature Review}

Various wide-ranging studies about English academic writing were conducted targeting both native and non-native speakers, comparing between them or merely focusing on their national background only to underscore the negative interference of the native language. Whereas Richards (1971) maintains that merely one-third of EFL students' errors result from their first language interference, (Bhela, 1999), Brown (1980), and Nemati and Taghizade, (2013) assert that most of EFL students' errors in the target language can be principally attributed to their belief that L1 and L2 systems are similar. Some studies particularly addressed ESL and EFL students in accordance with their national attribute such as the Chinese, Japanese, Indians, Vietnamese, Koreans, and Arabs (Note 4) just to name a few. Other studies investigated EFL students' writing based on their specialization, i.e. business, (Bacha \& Bahous, 2008; Al-Khasawneh \& Maher, 2010).

\subsection{The Causes of EFL Students' Writing Errors}

Many writing experts acknowledge that EFL students struggle and scuffle while attempting to write academic essays, and that writing per se can be a source of dejection and anxiety for these students. Such well-documented yet nerve-racking conundrums that challenge EFL students' competence and endurance have multidimensional grounds.

\subsubsection{Writing Mechanisms and Styles}

There are substantial discrepancies between the writing mechanisms of the first and the target languages. These discrepancies entail different morphological and phonological systems, diverse orthographies, dissimilar scripts, and even utterly diverse writing systems. Huerta et al. (2017) underscores the emotional dilemmas EFL students confront while writing academic essays. Moreover, due to the diverse nature of L1 writing style, L2 writing product can be deficient. Hinkel (1997) contends that the writing style of EFL students is vague, digressive and verbose: "speakers of Chinese, Korean, Japanese, and Indonesian utilised rhetorical questions and tags, disclaimers and denials, vagueness and ambiguity, repetition, several types of hedges, ambiguous pronouns, and the passive voice in greater frequencies than NSs did." 


\subsubsection{Critical Thinking}

EFL students' critical thinking skills could be another hindrance as theirs may differ from those required for English academic writing (Robrtson et al., 2000; Kumaravadivelu, 2003; Haung, 2008). Therefore, the cultural background is an essential element to be considered in this case. Critical thinking is a fundamental asset in writing, and it illustrates students' abilities to "identify issues and assumptions, recognise important relationships, make correct inferences, evaluate evidence or authority, and deduce conclusions" (Tsui, 2002, 743).

Ramanathan and Kaplan (1996) report that EFL students fail to convey the critical dimension in their writing and they encounter grave uneasiness and solemn distress in writing courses Similarly, Atkinson (1997) maintains that even teaching thinking to EFL students is charged with cultural impediments:

In both Japanese and Chinese schools, memorization and choral recitation are promoted as major learning strategies in the classroom, and writing instruction focuses centrally on the memorization and use of various formulaic phrases. Not surprisingly, innovation and individual creativity in writing are strongly discouraged at this level, if not automatically ruled out of court (p. 83).

\subsubsection{Plagiarism}

The term "academic writing" could be a new notion or a novel requirement for many international students and hence may elicit severe cases of plagiarism. According to Chien (2014), not only do EFL students lack sufficient dexterities in writing scientific essays, but they demonstrate remarkably ambivalent attitudes as to citing references. Such attitudes are fundamentally alien to the western conventions of source acknowledgement. In other words, what might be regarded as plagiarism in the English-speaking countries, might be not so in EFL students' home countries.

\subsection{Errors Made by Arabic Speakers in General}

Haggan (1991) attributes the errors made by Arabic speakers to the divergent scripts of Arabic and English. Moreover, unlike English, Arabic is spelled as pronounced. In this respect, Richards (1974) classifies spelling errors to "interlingual and false intralanguage analogy." Interlinguality ensues due to language transfer from L1 to L2, whereas intralanguage results from deficient learning of L1, or respectively from lack of practice.

In order to efficiently epitomise the causes of the numerous errors EFL Arab students make in writing, we utilise Zaharna's article "Understanding cultural preferences of Arab communication patterns (1995) whereby she remonstrates the cultural, historical, and social spectrum as a considerable impetus for the disparities between Arabic and English. While she marks the English-speaking societies as the "print" or the "literate," she labels the Arabic-speaking societies as the "oral." In this sense, the latter's language is replete with ambiguity, sentimentality, symbolism, and indirectness while the former's is characterised by directness, accuracy, and authenticity. Moreover, the author maintains that native speakers of English (Americans in this case) idolise doing over being. That is, unlike Arabs, they pay homage to individual achievement rather than to kin-based statuses or lineage. She further affirms that in Arabic, repetition and telling anecdotes are sufficient means of persuasion and are typically viewed as tributes among Arabic-speaking communities. However, for native speakers of English, such media involve unfavorable implications and may regard the written product as prolix, loquacious, and redundant. Along these lines, the cultural effect of Arabic perturbs the writing mission of EFL Arab students who may create a piece of writing that is ornamented, intuitive, overstated, and embellished rather than informational, logical, and analytical, content and evidence-based.

Zaharna adds that "it is not uncommon to find a string of descriptive phrases or words all referring to one phenomenon." This probably explains why EFL Arab students write run-on sentences or overextended, overstated paragraphs, let alone that sometimes one paragraph may make up the entire essay. Above and beyond, EFL Arab students are incompetent writers because Arabic is a non-linear, high-context language, hence the writing is collectivist, multi-thematic, multi-stimulus, metaphorical, suggestive, imaginative, and emotional. Contrariwise, English is a linear, low-context language that emphasises the cruciality of both beginnings and ends as well as documentation. Therefore, it is individual, pragmatic, realistic, provable, monothematic, stepwise, argument-driven, objective, understated, and methodical.

In the same vein, Mahmoud (1982) argues that EFL Arabic-speaking students lack significant parameters of writing: their writing is limited, invariant, and lacks coherence and reasoning. For most of them, academic writing is exceptionally strenuous due to the diglossic nature of the Arabic language. A study conducted by Khuwaileh and Al Shoumali (2000) reveal that "poor writing in English correlates with similar deficiencies in the mother tongue" (p. 174).

One holistic study that targeted EFL Arab students from eight countries -Iraq, Yemen, Syria, Libya, Saudi 
Arabia, Sudan, Palestine and Algeria- at Universiti Teknologi Malaysia examined the most common errors made by these students. The results revealed that the students' errors were most frequent in "vocabulary problems, spelling mistakes, expressing ideas, and organizing paragraphs" (Abdulkareem, 2013). By and large, EFL Arab students confront numerous barriers in English writing such as cohesion (Ahmed, 2010), and word patterns and grammar (Elachachi, 2015). According to Qaddumi (1995), Arab EFL students' writing teems with repetitive words, unparalleled, fragmental and incoherent sentences.

\subsection{Errors Made by EFL Arab-Israeli Students in Particular}

This research considers EFL Arab-Israeli students' errors in academic writing rather than in other types of writing. Hence, it goes unmentioned that along with the aforementioned barriers EFL Arab students have to tackle in general, the mission of creating an academic writing piece intensifies the challenge for EFL Arab-Israeli students.

It is common knowledge that Arabic is a metaphorical language, colloquially and formally speaking. Arabic writing, unlike English depends on lexical aesthetic devices rather than logic and reasoning. Hence, -and probably passionate proponents of Arabic will not find this comment flattering- we tend to agree with Kaplan (1966) who defines the Arabic rhetoric as a series of zigzags. Such "zigzags" are exceedingly palpable in the written samples of EFL Arab-Israeli students.

Moreover, the written essays under scrutiny were judged in relevance to academic writing features and, by no means were they mere impromptus. Namely, inasmuch as such essays might be regarded unqualified or inefficient in terms of academic writing, they might be regarded more than satisfactory in other writing domains.

Along these lines, academic writing as an overwhelming skill for EFL Arab-Israeli students involves more than just producing a written piece. Minding the rudiments of writing such as grammar and mechanics, organization, word order, subject-verb agreement, spelling, punctuation, and capitalization is fundamental yet not adequate. Academic writing necessitates vigorous practice that fosters critical reasoning, abstract thought, argumentation, and formal lexis not to mention tackling the triglossic nature of Arabic.

\section{Method}

To ascertain the reliability and the validity of the research we have employed methodological triangulation using two rating scales to gather data in addition to existing knowledge base.

\subsection{Research Design}

The research comprised three phases. In the first phase, a total of 44 (19 and 25) students enrolled in two multidimensional academic writing courses were given the same task whereby they were required to write a 300 -word essay. This phase lasted two hours. In the second phase, the students' writing skills were tested and assessed utilising two research tools and data were collected successively from both groups. In the third phase, the errors drawn were listed according to their frequency.

\subsection{Research Tools (Note 5)}

First, a source-based written task that was assessed by the researchers who have long-standing expertise in the field. Second, two rating scales from which the results were amalgamated. Third, the existing knowledge base of related literature was employed to explain the errors and their causes. One rating scale was a quantitative descriptive method and was managed to collect data (number of errors) from the students' written samples. This locally tailored assessment tool was designed to address possible EFL Arab-Israeli students' writing deficiencies and to gauge the accuracy of the essays. This tool included 5 main criteria (formality, sentence structure, grammar, mechanics, and lexis) and divided into 22 sub-criteria. The sub-criteria addressed errors of words, lexis, verb tense, punctuation, language (i.e. idiomatic), sentences (vagueness, fragments), spelling, articles, capitalizations, pronouns, contractions, word order, cohesion, run-ons, parallelism, apostrophe, passive, structure. This tool provided numerical values concerning the frequency of the writing errors. The second rating scale was a generic assessment tool which illustrated features of academic writing and was applied to analyse the errors related to the logical flow of the essays. This Likert-like rating scale ranging from 1-3 indicated the level of students' performance as (1) stood for mastery, (2) for average, and (3) for poor. Moreover, the tool comprised 5 criteria (objectivity, responsibility, organization, explicitness, complexity) divided into 11 sub-criteria illustrating.

\subsection{Participants}

A total of 44 EFL Arab-Israeli students were recruited from a College of Education located within the Green Line in the Haifa District of Israel. The participating students were juniors enrolled in an English teacher preparation 
program at the college. These students were not selected randomly but quite purposely as they comprised almost a perfect sample for the current research. The principal reason for selecting juniors rather than freshmen, sophomores, or seniors is because these students took two writing courses in the past two years, "Style and Composition" and "Written Expression." This being their first "Academic Writing" course, we wanted to evaluate their level in writing so as to unearth the most frequent errors they make and the plausible causes for such errors. We do not mean to claim that the problem will be completely solved but we believe that detecting these errors will help us single them out and address them more effectively so as to mitigate them respectively.

\section{Research Questions}

In order to unravel the common writing errors and the causes of the errors made by EFL Arab-Israeli students, three research questions were posited for the study:

1) What types of errors do EFL Arab-Israeli students make in academic writing?

2) Is the triglossic nature of first language interference the major cause for errors in the English writings of Arab-Israeli students?

3) What are the most common sources of academic writing errors in students' essays?

\section{Results}

Three main findings emerged from the current study. First, 44 students made 2965 errors. This is a relatively considerable number in proportion with the length of the essay. Second, according to the first rating scale, the most frequent errors were in explicitness and complexity, while the least frequent ones were in objectivity. Third, according to the second rating scale most frequent errors were in lexis (use of poor lexis and wrong words) and mechanics (spelling mistakes, capitalization errors and punctuation); while the least frequent errors were in formality (use of contractions, directives addressing the reader, informal, slang and idioms, numbered lists and bulleted items).

\subsection{Data Collection and Analysis}

\subsubsection{The Generic Assessment Tool: Logical Flow of Essay}

To rank the level of students' writing performance in general, descriptive statistics were used, and they revealed the following:

Table 1. The generic assessment tool

\begin{tabular}{llllll}
\hline Characterstics & N & Minimum & Maximum & Mean & SD \\
\hline Objectivity & 44 & 1.00 & 3.00 & 1.78 & .51 \\
Responsibility & 44 & 1.00 & 3.00 & 2.20 & .63 \\
Organization & 44 & 1.40 & 3.00 & 2.28 & .45 \\
Explicitness & 44 & 1.50 & 3.00 & 2.42 & .51 \\
Complexity & 44 & 2.00 & 3.00 & 2.70 & .46 \\
Total & 44 & 1.36 & 3.00 & 2.25 & .42 \\
\hline
\end{tabular}

As shown in the table above the students had average performance at objectivity $(\mathrm{M}=1.78, \mathrm{SD}=0.51)$, and almost poor performance at responsibility and organization, $(\mathrm{M}=2.20,2.28, \mathrm{SD}=0.63,0.45)$ on order, and poor performance at explicitness and complexity $(\mathrm{M}=2.42,2.70, \mathrm{SD}=0.51,0.46)$ on order. That is, students make many errors in complexity, and less errors in objectivity. For more details, the mean and slandered deviation of each item are ordered from the lowest (mastery) to the highest (poor) performance table:

Table 2. Sub-criteria of the generic assessment tool

\begin{tabular}{lllll}
\hline $\mathbf{N}$ & Item & N & Mean & SD \\
\hline 1 & (Organization): Length of essay is sufficient (around 300 words). & 44 & 1.4091 & .65833 \\
2 & $\begin{array}{l}\text { (Objectivity): Use of third person consistently rather than first and second persons. } \\
\text { No use of personal nouns. }\end{array}$ & 44 & 1.6818 & .60127 \\
& & & \\
\hline
\end{tabular}


3 (Objectivity): Description of argument accurately and without loaded or biased $44 \quad 1.8864 \quad .57933$ language.

4 (Explicitness): Appropriate use of transitional expressions

$\begin{array}{lll}44 & 2.0682 & .72810\end{array}$

5 Responsibility and Academic Conventions

$\begin{array}{lll}44 & 2.2045 & .63170\end{array}$

6 (Organization): The paper unfolds orderly and logically.

$\begin{array}{lll}44 & 2.3864 & .57933\end{array}$

7 (Objectivity): Diction is appropriate and not colloquial; the meaning is concise and $\quad 44 \quad 2.4091 \quad .58342$ formal

8 (Organization): Well developed, solid and cohesive paragraphs; paragraphs are $44 \quad 2.4773 \quad .50526$ evidence-based and support the author's opinion.

9 (Complexity): Critical, reflective, logical, and creative thinking rather than $44 \quad 2.7045 .46152$ descriptive or prescriptive thinking; use of concepts that describe abstract ideas

10 (Organization): The paper has an introduction, body, and conclusion $44 \quad 2.7273 \quad 62370$ (organization).

11 (Explicitness): Deep analysis of theme, genuine ideas.

$\begin{array}{lll}44 & 2.7727 & .42392\end{array}$

\subsubsection{The Locally Tailored Assessment Tool: Frequency of Writing Errors}

To find out the frequency of students' writing errors, descriptive statistics were used, and the results are illustrated in the following table:

Table 3. The locally tailored assessment tool

\begin{tabular}{llllll}
\hline Characteristics & $\mathbf{N}$ & Minimum & Maximum & Mean & SD \\
\hline Formality & 44 & .25 & 5.75 & 2.07 & 1.34 \\
Sentence Structure & 44 & .00 & 4.67 & 2.28 & 1.22 \\
Grammar & 44 & .00 & 5.71 & 2.74 & 1.33 \\
Mechanics & 44 & .00 & 8.67 & 3.95 & 2.09 \\
Lexis & 44 & 1.00 & 17.00 & 7.16 & 3.39 \\
Total & 44 & .18 & 6.64 & 3.06 & 1.39 \\
\hline
\end{tabular}

Table 4. Sub-criteria of the locally tailored assessment tool

\begin{tabular}{lllllll}
\hline Serial & & Valid & Mean & Minimum & Maximum & Sum \\
\hline 22 & Use of wrong words & 44 & 8.0909 & 0 & 20 & 356 \\
21 & Use of poor lexis/repetition. & 44 & 6.2273 & 2 & 14 & 274 \\
10 & Incorrect verb tense/no verb & 44 & 5.9318 & 0 & 12 & 261 \\
16 & Punctuation & 44 & 5.0227 & 0 & 11 & 221 \\
19 & Use of informal, slang and idioms. & 44 & 4.3864 & 1 & 10 & 193 \\
14 & Spelling mistakes & 44 & 3.8182 & 0 & 9 & 168 \\
7 & Incorrect subject-verb agreement & 44 & 3.2955 & 0 & 8 & 145 \\
1 & Vague and incomplete sentences. & 44 & 3.1136 & 0 & 9 & 137 \\
15 & Capitalization errors & 44 & 3.0909 & 0 & 7 & 136 \\
12 & Incorrect use of articles/lack of articles & 44 & 3.0682 & 0 & 6 & 135 \\
4 & Use of fragments & 44 & 3.0227 & 0 & 8 & 133 \\
11 & Indefinite pronouns (without clear antecedent) & 44 & 2.3182 & 0 & 6 & 102 \\
2 & Incorrect word order & 44 & 2.1591 & 0 & 5 & 95 \\
\hline
\end{tabular}




\begin{tabular}{|c|c|c|c|c|c|c|}
\hline 17 & Use of contractions. & 44 & 2.1591 & 0 & 7 & 95 \\
\hline 13 & Incorrect use of prepositions & 44 & 2.0909 & 0 & 7 & 92 \\
\hline 3 & Sentences are not related to the preceding ones & 44 & 2.0682 & 0 & 5 & 91 \\
\hline 5 & Use of run-ons & 44 & 1.6818 & 0 & 5 & 74 \\
\hline 6 & Lack of parallelism in a series of items & 43 & 1.6512 & 0 & 4 & 71 \\
\hline 9 & Incorrect use of apostrophe & 44 & 1.4091 & 0 & 5 & 62 \\
\hline 8 & Inappropriate use of passive voice & 44 & 1.1364 & 0 & 4 & 50 \\
\hline 18 & Use of directives addressing the reader. & 44 & 1.1364 & 0 & 5 & 50 \\
\hline 20 & Use of numbered lists and bulleted items & 44 & 0.5455 & 0 & 4 & 24 \\
\hline
\end{tabular}

As shown in tables 3 and 4 , students made less errors in formality $(\mathrm{M}=2.07, \mathrm{SD}=1.34)$, few more errors in sentence structure $(\mathrm{M}=2.28, \mathrm{SD}=1.22)$ and grammar $(\mathrm{M}=2.74, \mathrm{SD}=1.33)$, and much more errors in mechanics $(\mathrm{M}=3.95, \mathrm{SD}=2.09)$ and lexis $(\mathrm{M}=7.16, \mathrm{SD}=3.39)$. In other words, the most frequent errors are lexis (use of poor lexis and wrong words) and mechanics (spelling mistakes, capitalization errors and punctuation); while the least frequent errors are formality ones (use of contractions, directives addressing the reader, informal, slang and idioms, numbered lists and bulleted items). For more details, the mean and slandered deviation of each item are ordered from the most frequent errors to the least frequent errors in this table. The results help us to understand students' writing strengths and weaknesses.

\section{Discussion}

This section addresses the most common errors EFL Arab-Israeli students have made and causes of such errors.

\subsection{Triglossia}

According to the available results outputted from the data collection tools, the causes of most errors made by EFL Arab-Israeli students can be attributed to the negative transfer from Arabic into English recognised as first language interference. In the case of EFL Arab-Israeli students the triglossic nature of their mother tongue or the tri-lingual interference is the main cause. This is particularly evident as we associate the nature of Arabic as a repetitive, indirect, ambiguous, and multi-thematic language with the deficiency of appropriate lexis or poor lexis. Likewise, the wrong-word error could be attributed to the L1 students' lack of understanding of L2 register and connotation. Perhaps the results shown in the previous section can be best explained by Bhela (1999, p. 22) who maintains that "When writing or speaking the target language L2, second language learners tend to rely on their native language L1 structures to produce a response." That is, when the syntactical structure in the second language is different from that of the first language an error is more likely to occur. This is evident as the most frequent errors are in lexis and grammar, and these criteria have totally diverse systems in English and Arabic. Although capitalization, prepositions and spelling have dissimilar structures in both languages, their lower error frequency here can be attributed to the fact that they are not used as recurrently as lexis and grammar.

\subsubsection{Lexis and Grammar}

Namely, lexis cannot be viewed as a separate entity from that of grammar, therefore we find that both these categories are oriented in approximate domains successively with respect to the number of errors. In the current study, students' errors in grammar were mainly in the misuse of verb tenses and subject-verb agreement. Such hindrances can be also related to L1 interference. Because the linguistic systems of Arabic and Hebrew are entirely different from that of English, students attempting to apply the rules of the target language end up applying the rules of their mother tongue (Selinker, 1969; Mukattash, 1978). The results show that the other substantial grammatical errors made by the students were spelling, articles, and prepositions.

\subsubsection{Spelling}

The results show that 44 students have made 168 spelling errors. Olsson (1972) and Hendrickson (1977) maintain that spelling errors of international students could be linked to their lack of lexical competence and incorrect lexical choice, misuse or omission of prepositions and pronouns, omission of verbs, deficient subject-verb agreement.

Ibrahim (1978), organises spelling errors made by EFL Arab students into seven categories. Here we mention six 
of them. First, unlike English, Arabic is a phonetic language (laugh: laf; their: their, have: hav), and second, it has a different sound system ( $\mathrm{P}$ vs. B: problem: broblem - ben: pen). Third, the transitional invented error is often found in EFL students' writing (frys: fries). Fourth, correspondence is another issue to be considered (tend: frend). Fifth, words that challenge classification in English, homophony (need: reed). Sixth, English is incongruent and has random word-formation (hate: hatred but not hatered). Deacon (2017, pp.1-3) presents other five main frequent spelling errors made by EFL Arab learners. The first is "vowel blindness." The second is the consonant doubling error (hopping; writting). The third is silent misspelling (withe, playe); the fourth is the "incorrect vowel graph" (haight: height; organaise, organise), and the last is capitalization. We would like to further elaborate the second error provided by Ibrahim. Although there is an equivalent to P in Hebrew " $\mathrm{g}$," the problem does not materialise in the Hebrew spelling of EFL Arab-Israeli students but rather in English spelling. The reason for this could be attributed to the diverse magnitude and frequency of practice students receive in both disciplines. The second error provided by Deacon is very common among EFL Arab-Israeli students as Arabic and Hebrew are both abjads and hence do not have vowels but rather nunation.

\subsubsection{Articles}

Another substantial error made by EFL Arab students is the use of "articles." This situation results from the misapplication of the English article system. According to Hewson (1972, p. 131), "the definite and the indefinite article are among the ten most frequent words of English discourse." Similarly, Celce-Murcia and Larsen-Freeman (1999) avow that English articles are classified within the most common function words. Ionin et al. (2004) contend that Japanese learners overuse "the" in all indefinite specific contexts because their mother tongue lacks an article system. The authors attribute this overuse of articles to what they call "fluctuation." In the same vein, Jaensch and Sarko (2009) reveal that EFL Arab students use the definite article "The" fluctuated between the definite article "The" and the indefinite article "a" in indefinite specific contexts. Kharma (1981) maintains that half of the article errors in writing are ensued using the English "article system" by EFL Arab learners. Scott and Tucker (1974) also argue that EFL Arab students make considerable article errors. Folse (2008) maintains that internalizing the English article system by EFL students is not a trouble-free task as languages like Chinese, and Japanese lack such system. In like manner, EFL Arab learners overuse the article "The." Crompton (2011) concludes that the commonest errors result from the misuse of "The" for generic reference. Andersen (1984) attributes the reason of such quandary to the fact that the English article system is not composed of one-to-one form and meaning relationships.

In this research, articles errors were categorised as grammatical errors. Hence, they constituted $15.9 \%$ of this category. There is a piercing disparity between both Arabic and English article systems. Whereas the former demonstrates a dyadic model of defined and undefined nouns, the English system proposes a triadic model. Arabic singular and plural nouns are simply defined or undefined by adding or unadding the definite article Al: The.' To define English singular or plural nouns the definite article 'The' is added, whereas undefined nouns are characterised by adding the indefinite articles ' $a$ ' and ' $n$ ' for singular nouns and unadding them in case of plural nouns. Hence, in/definiteness in English is indicated by lexical elements such as 'a' 'an' and 'the' while in Arabic it is designated by the prefix 'Al.'

\subsubsection{Prepositions}

The use of prepositions is another momentous handicap for EFL students who usually attempt to translate English prepositions to their mother tongue (James, 1996) and (Gass, 1983). Therefore, they struggle when using English prepositions (Pittman, 1966; Celce-Muricia \& Larsen, 1983). Trujillo (1995) argues that EFL learners have difficulties with the prepositions due to the latter's decidedly polysemous behaviour and idiomatic nature. Whereas spatial and temporal prepositions were studied intensely, other types of prepositions such as instrument, amount and manner are largely unexamined. Prepositions pose a number of challenges for Arab EFL students because of cross-linguistic disparities between the prepositional system Arabic and English. Over and above, there are more prepositions in English than Arabic and there are even prepositions in English that have no equivalents or do not materialise in the Arabic language. Compared to Arabic which has twenty prepositions (Hassan, 1961) English has one hundred fifty prepositions (Essberger, 2012). Such disproportion produces meaningful and myriad preposition-related errors.

\subsection{Responsibility}

It is evident that EFL Arab-Israeli students have not scored well in the responsibility criterion which could be as well attributed to the fact that Arabic is an anecdotal, metaphorical, collectivist language rather than an evidence-driven one. Only $11.4 \%$ of the students acknowledged the provided source properly while the $56.8 \%$ partially acknowledged it or insufficiently acknowledged it. That is, some of the students used in-text citations 
with quotation marks but did not provide a reference list, or they have not used a proper citation style. The remaining $31.8 \%$ have used the source but did not acknowledge it. The reason for this could be ascribed to the fact that "academic writing" in western standards is different from "academic writing" in oriental standards.

\section{Research Limitations}

Despite the considerably representative results, the present study has limitations that should be taken into account when interpreting the findings. First, though proved efficient, the type of the task is not fully representative for the less common writing sub-criteria such as the incorrect use of apostrophes, lack of parallelism, and passive voice. We noticed that some students did not even use these items because the task was not customised to meet such a goal. Therefore, it would be useful for future research to use other types of tasks in addition to the primary task so as to capture these items. A second issue to be considered is essay length and the time allotted for the writing task. The students were asked to write a 300-word essay and the time allotted for this task was a total of 2 hours. This fact has two implications. First, longer essays will have more errors and more time might alleviate the number of errors. Therefore, had the students written two essays of different lengths or two essays of identical lengths but with varied time spans, the results would have been more effective and more expressive.

\section{Conclusion}

Despite available large-scale studies investigating EFL/ESL students' writing difficulties and most common errors, research examining EFL Arab-Israeli students' in general and writing performance in particular remains scarce or even undone. This can simply be explained as both words "Israeli" and "Arab" insinuate historical and political connotations and are predominantly regarded as antonyms, adversaries, and enemies, i.e. the "Arab-Israeli" conflict. To add, this hyphenated combination of "Arab-Israeli" is rarely viewed as a means of integration or amalgamation as it stands here. Despite the fact that its demographic representation comprises $21 \%$ of Israel's overall population (Brookdale, 2018), the Arab-Israeli minority is still highly marginalised and underrepresented (Adala, 2011). Such representation, rather, is squeezed between the Palestinian rock and the Israeli hard place. Therefore, the status of Arab-Israelis has dissipated in each and every aspect, and English learning is no exception.

In this research we attempted to locate the most common errors in the writing of this particular group of students so as to find ways that tackle such specific errors. Nonetheless, EFL Arab-Israeli students undoubtedly constitute an integral part of both the local Arab community worldwide with whom they share the same language and history, and successively, they are also a part of the universal community of EFL students. In this research we have shown the unyielding correspondence between the errors made by EFL Arab-Israeli students and the other two groups. Perhaps the main difference lies in the triglossic nature of the Arabic language used by the former. Hopefully, screening this particular declassed micro-level group will add another valuable and substantial dimension to the macro-level field of English teaching and learning.

\section{Acknowledgments}

We would like to thank both Al-Qasemi College and The Research Unit for their generous support funding this research paper, Research No. (872E), entitled "The most frequent errors in academic writing: A case of EFL undergraduate Arab students in Israel". Much gratitude goes to all the students in the English department who participated in this study.

\section{References}

Abdulkareem, M. N. (2013). An Investigation study of academic writing problems faced by Arab postgraduate students at Universiti Teknologi Malaysia (UTM). Theory and Practice in Language Studies, 3(9). https://doi.org/10.4304/tpls.3.9.1552-1557

Adalah. (2011). The legal center for Arab minority rights in Israel. Retrieved from https://www.adalah.org/uploads/oldfiles/upfiles/2011/Adalah_The_Inequality_Report_March_2011.pdf

Ahmed, A. H. (2010). Students' problems with cohesion and coherence in EFL essay writing in Egypt: Different perspectives. Literacy Information and Computer Education Journal, 211-221. https://doi.org/10.20533/ licej.2040.2589.2010.0030

Al-Khasawneh, F. M. S. (2010). Writing for academic purposes: Problems faced by Arab postgraduate students of the college of business. UUM. ESP World, 28(9), 1-23.

Al-Sohbani, Y. A. (2015). The role of attitudes and motivation in learning English as a foreign language among Yemeni rural secondary school students. Journal of Teaching and Teacher Education, 3(1), 33-42. https://doi.org/10.12785/jtte/030103

Al-Zubaidi, K. O. (2012). The academic writing of Arab postgraduate students: Discussing the main language 
issues. Procedia - Social and Behavioral Sciences, 3(66), 46-52. https://doi.org/10.1016/ j.sbspro.2012.11.246

Amara, M., Schmidt-Donitsa, S., \& Mar'i, A. (2016). Arabic in the Israeli academy: Historical absence, current challenges, and future possibilities. Retrieved from https://www.researchgate.net/profile/Muhammad_Amara/publication/312219327_Arabic_in_the_Israeli_A cademy_Historical_absence_current_challenges_and_future_possibilities/links/58805ea408ae $4445 \mathrm{c} 0726 \mathrm{~d} 2$ f/Arabic-in-the-Israeli-Academy-Historical-absence-current-challenges-and-future-possibilities.pdf

Andersen, R. W. (1984). The one-to-one principle of interlanguage construction. Language Learning, 34, 77-95. https://doi.org/10.1111/j.1467-1770.1984.tb00353.x

Atkinson, D. (1997). A Critical approach to critical thinking in TESOL. TESOL Quarterly, 31(1), 71. https://doi.org/10.2307/3587975

Bacha, N. N., \& Bahous, R. (2008). Contrasting views of business students' writing needs in an EFL environment. English for Specific Purposes, 27(1), 74-93. https://doi:10.1016/j.esp.2007.05.001

Beaudet, C., Graves, R \& Labasse, B. (2011). Writing under the influence (of the writing process). In V. Berninger (Ed.), Past, present, and future contributions of cognitive writing research to cognitive psychology (pp. 105-134). New York: Psychology Press.

Bhela, B. (1999). Native language interference in learning a second language: Exploratory case studies of native language interference with target language usage. International Education Journal, 1(1), 22-31.

Boguraev, B., \& Spark, J. K., (1987). Material concerning a study of cases, Tech. Report 118. University of Cambridge Computer Laboratory.

Celce - Murcia, M., \& Freeman, L. (1983). The grammar book. Rowley, MA: Newbury House Publishers.

Chien, S.-C. (2014). Cultural constructions of plagiarism in student writing: Teachers' perceptions and responses. Research in the Teaching of English, 49(2), 120.

Cook, V. (1997). L2 users and English spelling. Journal of Multilingual and Multicultural Development, 18(6), 474-488. https://doi.org/10.1080/01434639708666335

Crompton, P. (2011). Article errors in the English writing of advanced L1 Arabic learners: The role of transfer. Professional Teachers' Article, 50, 1-33. Retrieved from www.asian-efl-journal.com

Gass, S., \& Selinker, L. (1983). Language transfer in language learning. MA: Newbury House Publishers, Inc.

Deacon, R. J. (2017). The causes of spelling errors by Arabic learners of English. Eurasian Journal of Applied Linguistics, 3(2), 1-22. https://doi.org/10.32601/ejal.460951

Djos, M. (2010). Writing under the influence: Alcoholism and the alcoholic perception from Hemingway to Berryman. Basingstoke, England: Springer. https://doi.org/10.1057/9780230109131

Elachachi, H. (2015). Exploring cultural barriers in EFL Arab learners' writing. Procedia-Social and Behavioral Sciences, 199, 129-136. https://doi.org/10.1016/j.sbspro.2015.07.496

Essbereger, J. (2012). English prepositions list. Retrieved from https://www.jcu.edu.au/_data/assets/pdf_file/ 0016/104119/jcu_128219.pdf

Ferguson, C. A. (1959). Diglossia. WORD, 15(2), 325-340. https://doi.org/10.1080/00437956.1959.11659702

Folse, K. S. (2008). Myth 1: Teaching vocabulary is not the writing teacher's job. In J. Reid (Ed.), Writing myths: Applying second language research to classroom teaching (pp. 1-17). Ann Arbor, MI: University of Michigan Press.

Garner, B. (2009). Garner's modern American usage. New York, NY: Oxford University Press, USA.

Gass, S. (1978). Language transfer and universal grammatical relations. Language Learning, 29, 327-344. https://doi.org/10.1111/j.1467-1770.1979.tb01073.x

Haggan, M. (1991). Spelling errors in native Arabic-speaking English majors: A comparison between remedial students and fourth year students. System, 19(1-2), 45-61. https://doi.org/10.1016/0346-251X(91)90007-C

Hassan, A. (1961). Al-nahw al-wafi. Cairo: Dar Al-Maaref. Retrieved from http://shamela.ws/index.php/ book/10641

Hendrickson, J. M. (1977). Error analysis and selective correction in the adult ESL classroom: An experiment. ERIC: Centre for Applied Linguistics, Arlington, Virginia. EDRS: ED 135260. 
Hinkel, E. (1997). Indirectness in L1 and L2 academic writing. Journal of Pragmatics, 27(3), 361-386. https://doi.org/10.1016/S0378-2166(96)00040-9

Huang, R. (2008). Critical thinking: Discussion from Chinese postgraduate international students and their lecturers. Hospitality, Leisure, Sport and Tourism Education, 4(23), 1-12.

Huerta, M., Goodson, P., Beigi, M., \& Chlup, D. (2016). Graduate students as academic writers: writing anxiety, self-efficacy and emotional intelligence. Higher Education Research \& Development, 36(4), 716-729. https://doi.org/10.1080/07294360.2016.1238881

Ibrahim, M. (1978). Patterns in spelling errors. English Language Teaching Journal, 32(3), 207-212. https://doi.org/10.1093/elt/XXXII.3.207

Introduction to Academic Writing. (n.d.) Retrieved from https://www.jcu.edu.au/_data/assets/pdf_file/ 0006/118608/jcuprd1_071903.pdf

Ionin, T., Ko, H., \& Wexler, K. (2004). Article semantics in L2 acquisition: The role of specificity. Language Acquisition, 12(1), 3-69. https://doi.org/10.1207/s15327817la1201_2

Jackson, M. (2012). Writing under the Influence. The Other Shore, 16-19. https://doi.org/10.1525/ california/9780520275249.003.0004

James, C. (1996). A cross-linguistic approach to language awareness. Language Awareness, 5, 138-148. https://doi.org/10.1080/09658416.1996.9959903

Jaensch, C., \& Sarko, G. (2009). Sources of fluctuation in article choice in English and German by Syrian Arabic and Japanese native speakers. EUROSLA Yearbook, 9, 33-55. https://doi.org/10.1075/eurosla.9.04jae

Kaplan, R. B. (1966). Cultural thought patterns in inter-cultural education. Language Learning, 16(1-2), 1-20. https://doi.org/10.1111/j.1467-1770.1966.tb00804.x

Kharma, N. (1981). Analysis of the errors committed by Arab university students in the use of the English definite/indefinite articles. IRAL - International Review of Applied Linguistics in Language Teaching, 19(1-4). https://doi:10.1515/iral.1981.19.1-4.333

Khuwaileh, A. A., \& Shoumali, A. A. (2000). Writing errors: A study of the writing ability of Arab learners of academic English and Arabic at university. Language, Culture and Curriculum, 13(2), 174-183. https://doi.org/10.1080/07908310008666597

Kumaravadivelu, B. (2003). A Postmethod perspective on English language teaching. World Englishes, 22(4), 539-550. https://doi:10.1111/j.1467-971x.2003.00317.x

Mahmoud, A. (1982). A functional analysis of written compositions of Egyptian students of English and the implications of the notional functional syllabus for the teaching of writing. Dissertation Abstracts International, 44(5), 1439A.

Mukattash, L. (1978). A Pilot project in common grammatical errors in Jordanian English, Interlanguage Studies Bulletin, 3(2), 250-299

Myers-JDC-Brookdale Institute. (2018). The Arab population in Israel: facts \& figures 2018. Retrieved from https://brookdale.jdc.org.il/wpcontent/uploads/2018/03/MJB_Facts_and_Figures_on_the_Arab_Population _in_Israel_2018-English.pdf

Olsson, M. (1972). Intelligibility: A study of errors and their importance. Research Bulletin, 12, Department of Educational Research Gothenburg School of Gothenburg, Sweden, ERIC Microfiche ED 072681.

Qaddumi, M. (1995). Textual deviation and coherence problems in the writing of Arab students at the University of Bahrain: Sources and solutions (Doctoral dissertation, University of Nottingham, UK).

Qaid, Y. A., \& Ramamoorthy, L. (2011). Analysis of intralingual errors in learning English as a foreign language by Yemeni Students, Academic Journal, Language in India, 11(5), 534.

Pittman, G. A. (1966). Activating the use of prepositions. London: Longmans, Green and Co., Ltd.

Ramanathan, V., \& Kaplan, R. (1996). Some problematic "channels" in the teaching of critical thinking in current L1 composition textbooks: Implications for L2 student-writers. Issues in Applied Linguistics, 7, 225-249.

Richards, J. C. (Ed.) (1974 a). Error analysis: Perspectives on second language acquisition. London; New York: Longman. 
Richards, J. C. (1971 b). A non-contrastive approach to error analysis. English Language Teaching Journal, 25, 204-229. https://doi.org/10.1093/elt/XXV.3.204

Robertson, M., Line, M., Jones, S., \& Thomas, S. (2000). International students, learning environments and perceptions: A case study using the Delphi technique. Higher Education Research \& Development, 19(1), 89-102. https://doi:10.1080/07294360050020499

Scott, M. S., \& Tucker, G. R. (1974). Error analysis and English-language strategies of Arab students. Language Learning, 24(1), 69-97. https://doi.org/10.1111/j.1467-1770.1974.tb00236.x

Selinker, L. (1969). Language transfer. General Linguistics, 9(2), 67-92.

Smith, T. (2006). Recent trends in undergraduate writing courses and programs in Canadian Universities. In R. Graves, \& H. Graves (Eds.), Writing centers, writing seminars, writing culture: Writing instruction in Anglo-Canadian Universities (pp. 319-370). Winnipeg, MB, Canada: Inkshed Press.

Thomason, S. G., \& Kaufman, T. (1992). Language contact, creolization, and genetic linguistics. Oakland, CA: University of California Press.

Trujillo, A. (1995). Lexicalist machine translation of spatial prepositions (Doctoral dissertation, University of Cambridge).

Tsui, L. (2002). Fostering critical thinking through effective pedagogy: Evidence from four institutional case studies. The Journal of Higher Education, 73(6), 740-763. https://doi.org/10.1353/jhe.2002.0056

University of Sheffield. (2016, October 14). Style - academic writing - writing - study Skills - 301 - SSiD. Retrieved from https://www.sheffield.ac.uk/ssid/301/study-skills/writing/academic-writing

USC Libraries Research Guide. (n.d.). Research guides: Organizing your social sciences research paper: Academic writing style. Retrieved from http://libguides.usc.edu/writingguide/academicwriting

Verkuyl, H., \& Zwarts, J., (1992), Time and space in conceptual and logical semantics: The notion of path, Linguistics, 30, 483-511. https://doi.org/10.1515/ling.1992.30.3.483

Zaharna, R. (1995). Understanding cultural preferences of Arab communication patterns. Public Relations Review, 21(3), 241-255. https://doi.org/10.1016/0363-8111(95)90024-1

\section{Appendices}

Appendix A. Results derived from the generic assessment tool

The paper has an introduction, body, and conclusion (Organization 1)

\begin{tabular}{lllll}
\hline & $\mathrm{F}$ & $\mathrm{P}$ & $\mathrm{VP}$ & $\mathrm{CP}$ \\
\hline Mastery & 4 & 9.1 & 9.1 & 9.1 \\
Average & 4 & 9.1 & 9.1 & 18.2 \\
Poor & 36 & 81.8 & 81.8 & 100.0 \\
Total & 44 & 100.0 & 100.0 & \\
\hline
\end{tabular}

$\mathrm{F}=$ Frequency; $\mathrm{P}=$ Percent; $\mathrm{VP}=$ Valid Percent $\mathrm{CP}=$ Cumulative Percent. 


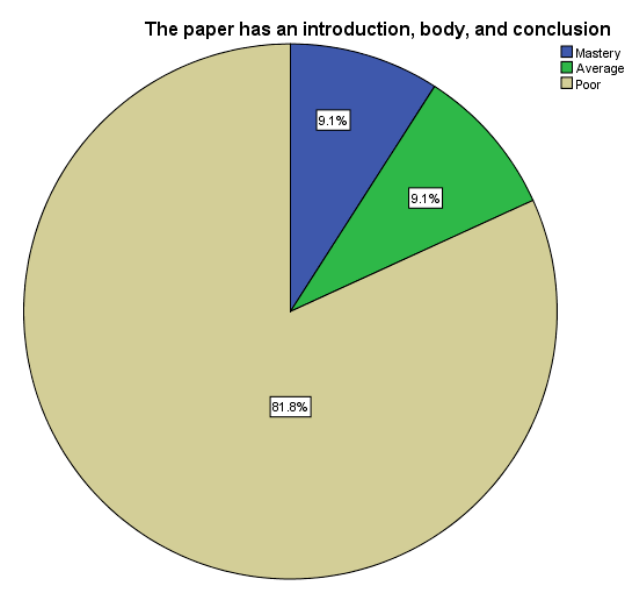

Appendix B. The paper unfolds orderly and logically (Organization 2)

\begin{tabular}{lllll}
\hline & $\mathrm{F}$ & $\mathrm{P}$ & $\mathrm{VP}$ & $\mathrm{CP}$ \\
\hline Mastery & 2 & 4.5 & 4.5 & 4.5 \\
Average & 23 & 52.3 & 52.3 & 56.8 \\
Poor & 19 & 43.2 & 43.2 & 100.0 \\
Total & 44 & 100.0 & 100.0 & \\
\hline
\end{tabular}

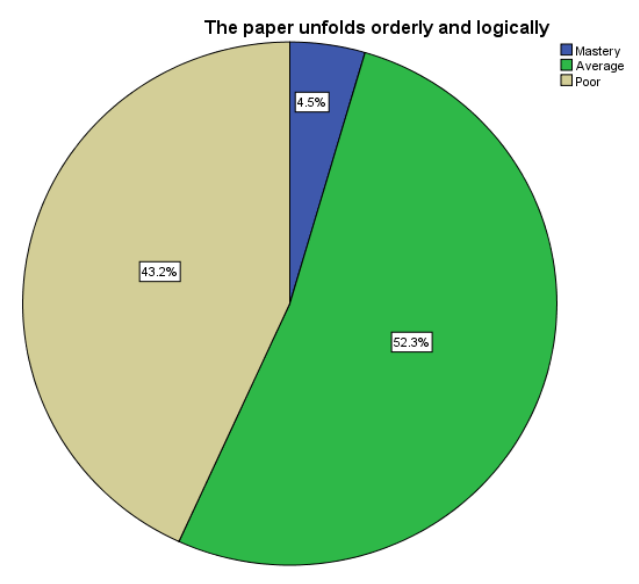

Appendix C. Length of essay is sufficient (Organization 3)

\begin{tabular}{lllll}
\hline & F & P & VP & CP \\
\hline Mastery & 33 & 75.0 & 75.0 & 75.0 \\
Average & 7 & 15.9 & 15.9 & 90.9 \\
Poor & 4 & 9.1 & 9.1 & 100.0 \\
Total & 44 & 100.0 & 100.0 & \\
\hline
\end{tabular}




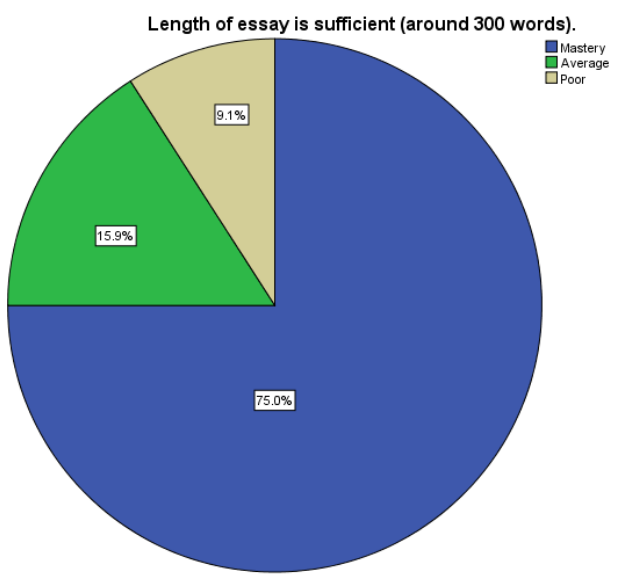

Appendix D. Well developed, solid and cohesive paragraphs; Paragraphs are evidence-based and support the author's opinion with evidence or relevant examples (paragraph level)

\begin{tabular}{lllll}
\hline & F & P & VP & CP \\
\hline Average & 23 & 52.3 & 52.3 & 52.3 \\
Poor & 21 & 47.7 & 47.7 & 100.0 \\
Total & 44 & 100.0 & 100.0 & \\
\hline
\end{tabular}

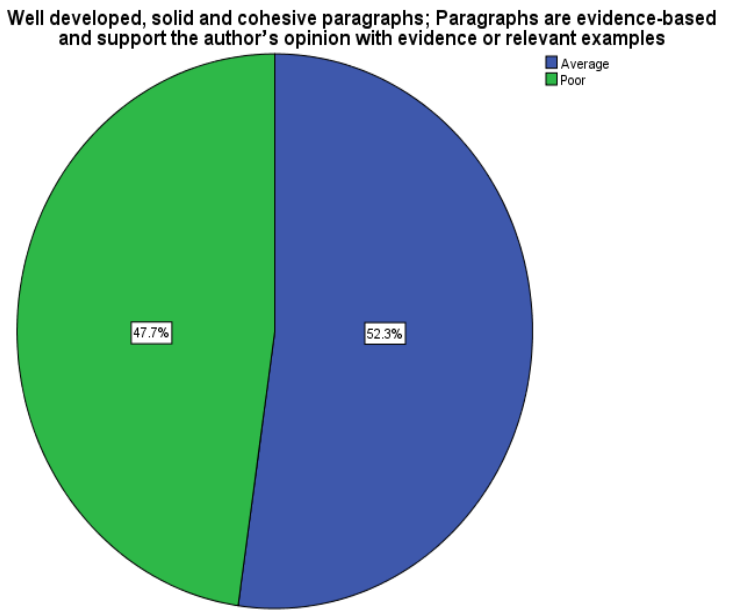

Appendix E. Diction is appropriate and not too colloquial; the meaning is concise and formal (Objectivity3)

\begin{tabular}{lllll}
\hline & $\mathrm{F}$ & $\mathrm{P}$ & $\mathrm{VP}$ & $\mathrm{CP}$ \\
\hline Mastery & 2 & 4.5 & 4.5 & 4.5 \\
Average & 22 & 50.0 & 50.0 & 54.5 \\
Poor & 20 & 45.5 & 45.5 & 100.0 \\
Total & 44 & 100.0 & 100.0 & \\
\hline
\end{tabular}




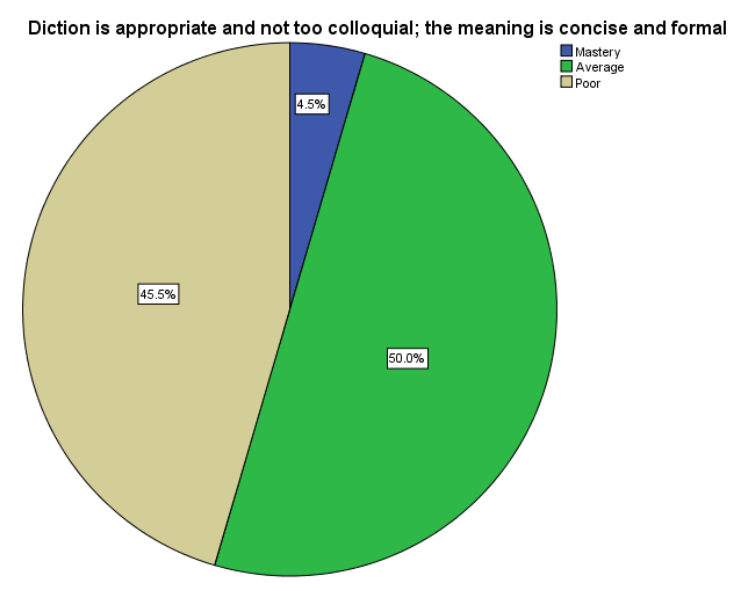

Appendix F. Appropriate use of transitional expressions (Explicitness 1)

\begin{tabular}{lllll}
\hline & $\mathrm{F}$ & $\mathrm{P}$ & $\mathrm{VP}$ & $\mathrm{CP}$ \\
\hline Mastery & 10 & 22.7 & 22.7 & 22.7 \\
Average & 21 & 47.7 & 47.7 & 70.5 \\
Poor & 13 & 29.5 & 29.5 & 100.0 \\
Total & 44 & 100.0 & 100.0 & \\
\hline
\end{tabular}

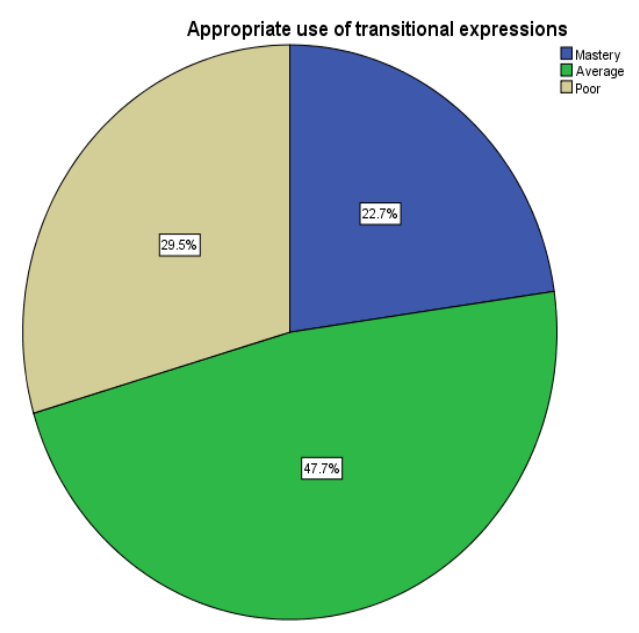

Appendix G. Deep analysis of theme, genuine ideas (Explicitness 2)

\begin{tabular}{lllll}
\hline & $\mathrm{F}$ & $\mathrm{P}$ & $\mathrm{VP}$ & $\mathrm{CP}$ \\
\hline Average & 10 & 22.7 & 22.7 & 22.7 \\
Poor & 34 & 77.3 & 77.3 & 100.0 \\
Total & 44 & 100.0 & 100.0 & \\
\hline
\end{tabular}




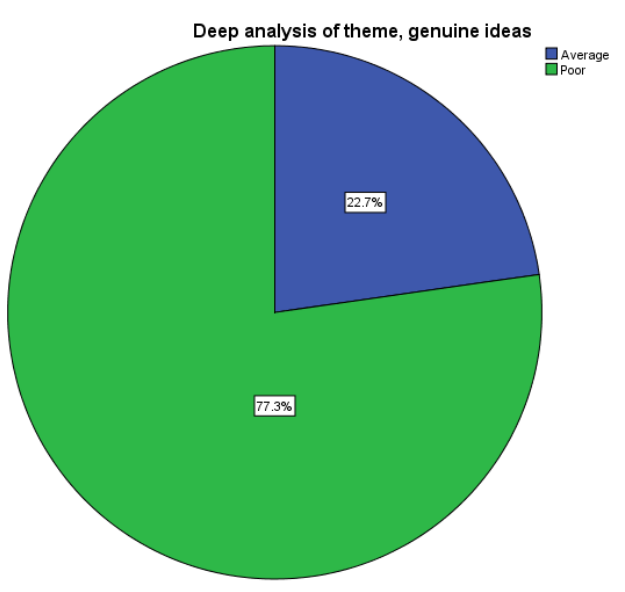

Appendix H. Use of third person consistently rather than first and second persons. No use of personal nouns (Objectivity 1)

\begin{tabular}{lllll}
\hline & $\mathrm{F}$ & $\mathrm{P}$ & $\mathrm{VP}$ & $\mathrm{CP}$ \\
\hline Mastery & 16 & 36.4 & 36.4 & 36.4 \\
Average & 25 & 56.8 & 56.8 & 93.2 \\
Poor & 3 & 6.8 & 6.8 & 100.0 \\
Total & 44 & 100.0 & 100.0 & \\
\hline
\end{tabular}

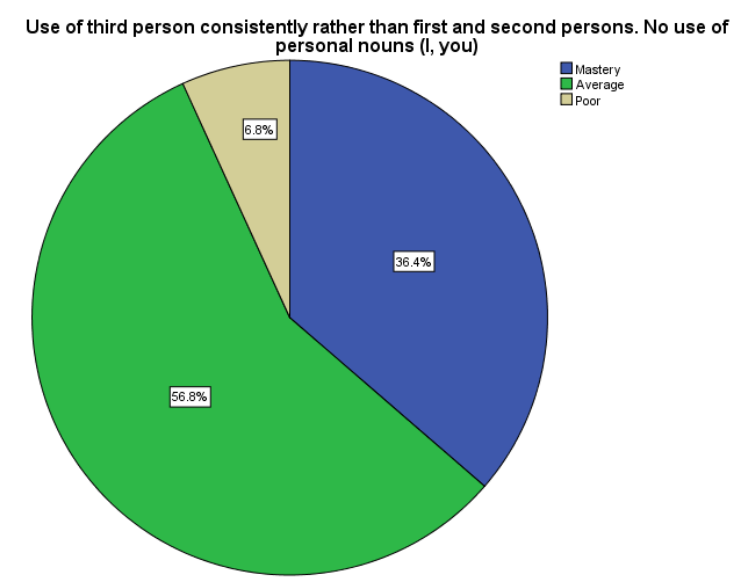

Appendix I. Description of argument accurately and without loaded or biased language (Objectivity 2)

\begin{tabular}{lllll}
\hline & $\mathrm{F}$ & $\mathrm{P}$ & $\mathrm{VP}$ & $\mathrm{CP}$ \\
\hline Mastery & 11 & 25.0 & 25.0 & 25.0 \\
Average & 28 & 63.6 & 63.6 & 88.6 \\
Poor & 5 & 11.4 & 11.4 & 100.0 \\
Total & 44 & 100.0 & 100.0 & \\
\hline
\end{tabular}




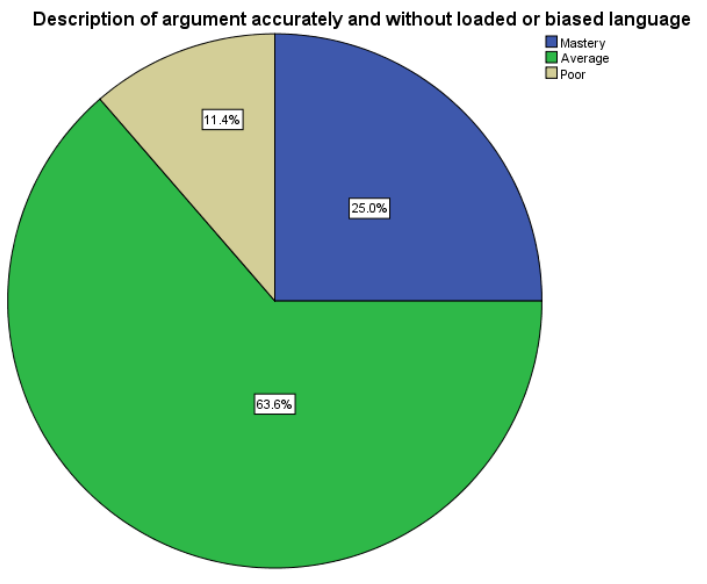

Appendix J. Critical, reflective, logical, and creative thinking rather than descriptive or prescriptive thinking; use of concepts that describe abstract ideas

\begin{tabular}{lllll}
\hline & $\mathrm{F}$ & $\mathrm{P}$ & $\mathrm{VP}$ & $\mathrm{CP}$ \\
\hline Average & 14 & 31.8 & 31.8 & 31.8 \\
Poor & 30 & 68.2 & 68.2 & 100.0 \\
Total & 44 & 100.0 & 100.0 & \\
\hline
\end{tabular}

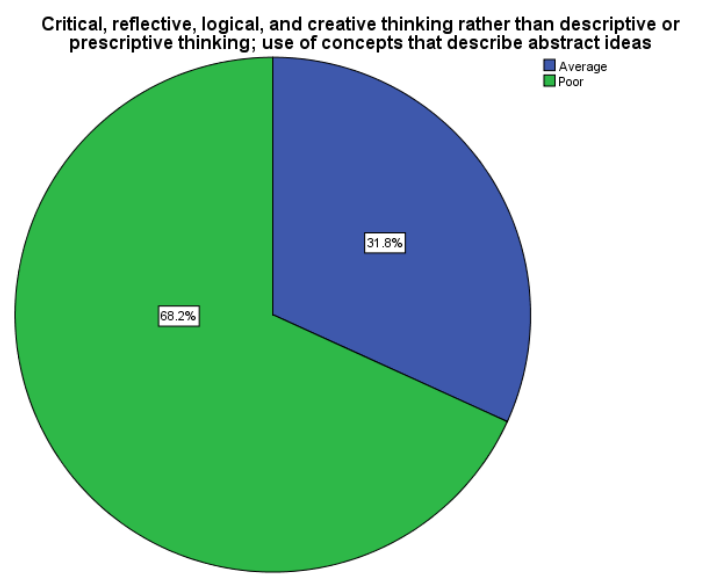

Appendix K. Correct use of referencing; Citing sources in the body of the paper and providing a list of references (Responsibility)

\begin{tabular}{lllll}
\hline & $\mathrm{F}$ & $\mathrm{P}$ & $\mathrm{VP}$ & $\mathrm{CP}$ \\
\hline Mastery & 5 & 11.4 & 11.4 & 11.4 \\
Average & 25 & 56.8 & 56.8 & 68.2 \\
Poor & 14 & 31.8 & 31.8 & 100.0 \\
Total & 44 & 100.0 & 100.0 & \\
\hline
\end{tabular}




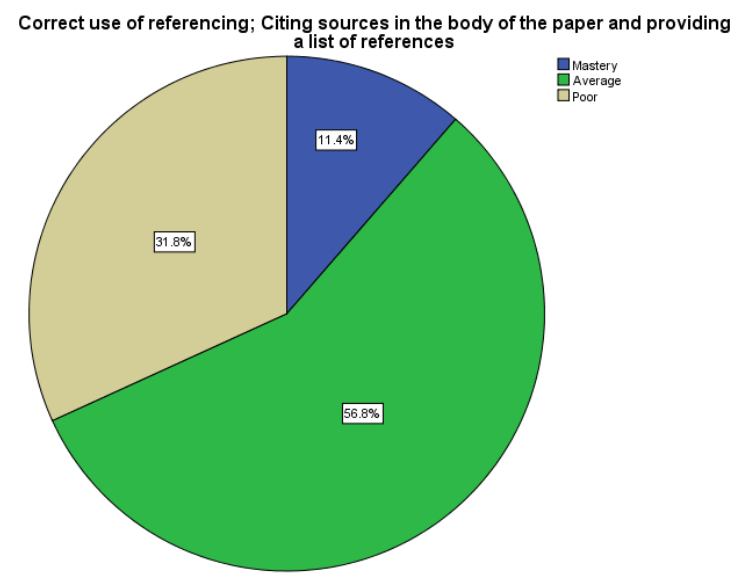

Appendix L. Statistics

\begin{tabular}{|c|c|c|c|}
\hline & Valid & Mean & SD \\
\hline The paper has an introduction, body, and conclusion & 44 & 2.7273 & .62370 \\
\hline The paper unfolds orderly and logically & 44 & 2.3864 & .57933 \\
\hline Length of essay is sufficient (around 300 words). & 44 & 1.3409 & 64495 \\
\hline $\begin{array}{l}\text { Well developed, solid and cohesive paragraphs; Paragraphs are evidence-based } \\
\text { and support the author's opinion with evidence or relevant examples }\end{array}$ & 44 & 2.4773 & .50526 \\
\hline Diction is appropriate and not too colloquial; the meaning is concise and formal & 44 & 2.4091 & .58342 \\
\hline Appropriate use of transitional expressions & 44 & 2.0682 & .72810 \\
\hline Deep analysis of theme, genuine ideas & 44 & 2.7727 & .42392 \\
\hline $\begin{array}{l}\text { Use of third person consistently rather than first and second persons. No use of } \\
\text { personal nouns (I, you) }\end{array}$ & 44 & 1.7045 & .59375 \\
\hline Description of argument accurately and without loaded or biased language & 44 & 1.8636 & .59419 \\
\hline $\begin{array}{l}\text { Critical, reflective, logical, and creative thinking rather than descriptive or } \\
\text { prescriptive thinking; use of concepts that describe abstract ideas }\end{array}$ & 44 & 2.6818 & .47116 \\
\hline $\begin{array}{l}\text { Correct use of referencing; Citing sources in the body of the paper and } \\
\text { providing a list of references }\end{array}$ & 44 & 2.2045 & .63170 \\
\hline
\end{tabular}




\section{Appendix M. Errors}

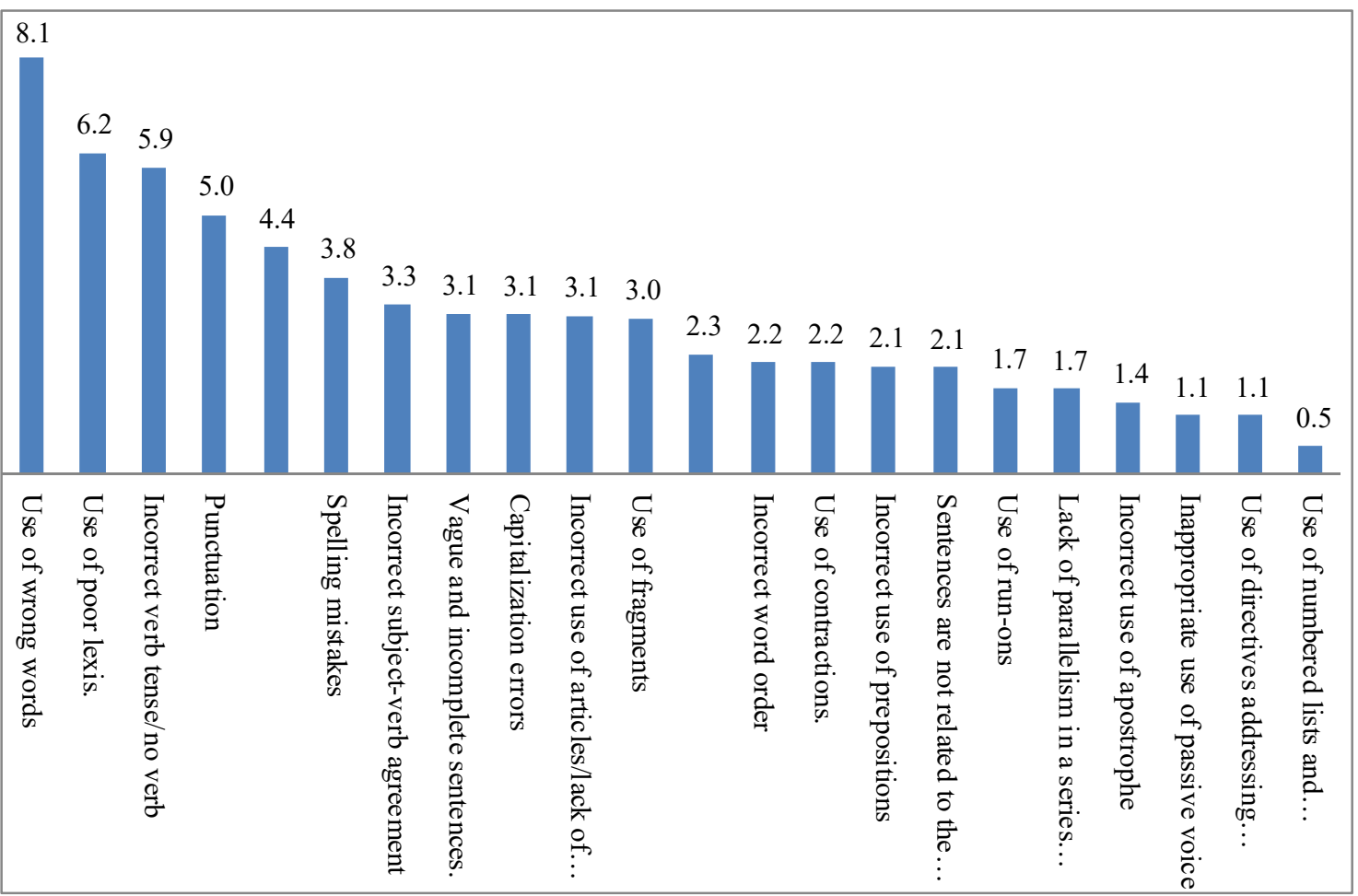

\section{Notes}

Note 1. James Hock University Learning Center.

Note 2. Also called language transfer.

Note 3. Translated from Hebrew.

Note 4. Such as Lee, S. N., \& Tajino, A. (2008); Chou, L. (2011)

Note 5 . The rating scales designed by the researchers were partially adapted from existing.

\section{Copyrights}

Copyright for this article is retained by the author(s), with first publication rights granted to the journal.

This is an open-access article distributed under the terms and conditions of the Creative Commons Attribution license (http://creativecommons.org/licenses/by/4.0/). 